Litinfinite Journal

ISSN: 2582-0400 [Online]

CODEN: LITIBR

Vol-1, Issue-2 (2 ${ }^{\text {nd }}$ December, 2019)

Page No: $11-18$

DOI: 10.47365/litinfinite.1.2.2019.11-18

Section: Article

\title{
The Forgotten Playwright: Ramanarayan Tarkaratna
}

\author{
Nirban Nandy \\ Guest Faculty - Department of English \\ University of Engineering and Management - Kolkata, West Bengal, India. \\ Mail Id: englishhons.nirban.nandy@gmail.com
}

\begin{abstract}
Ramanarayan Tarkaratna (1822-1886) was a predecessor of the great figure of Bangla as well as of Indian literature(s) Michael Madhusudan Dutt; though nearly forgotten at present, once Ramanarayan was an eminent and prominent personality of the Bangla theatrical space. I would like to consider him as the guiding figure of realistic poetics of Bangla theatre. In 1854, his play Kulinkulasarbaswa dawned on the new age of Bangla theatre. The play is the first original Bangla play to be staged; it also has the merit of being the first-ever original Bangla play dealing with the serious social evils such as Kulin system of the Bengal Brahminism enforced by King Ballala Sena of the Sena Dynasty, and also polygamous ventures undertaken by Brahmin males. With these primary problems at stake, the play also deals with related issues such as education for women, women and society, and marriage. The composition and enactment of the play, Kulinkulasarbaswa, successfully began a new theatrical movement with a progressive outlook and inclusive nature. Ramanarayan, as a playwright, stands as the bridge between the olden forms of Sanskrit drama, and various folk practices (like jatra, palagan, etc) and the youthful arrival of the western theatrical practices, aesthetics and dramaturgy. Not only as a dramatist, but also on the merit of being a person of progressive mentality has Ramanarayan chosen to stand with the progressive side of the then Bengal intelligentsia including Ishwarchandra Vidyasagar, Madanmohan Tarkalankar, et al. His plays, including his magnum opus Kulinkulasarbaswa and Nabanataka, advocate progressive consciousness and warm welcome towards the arrival of the new. The paper aims at the reading and analysis of the plays by Ramanarayan Tarkaratna, with special focus upon his masterpiece Kulinkulasarbaswa to trace the socio-literary changes occurring in the $19^{\text {th }}$ century; the entrance of new consciousness; and the quest and establishment of a new identity.
\end{abstract}

Keywords: Bangla theatre, progression, drama, society

Let us go back to October 1853. The Head Pundit of Hindu Metropolitan College was addressing his students. In that public lecture, the Head Pundit said: "Bangla is the mother tongue of this land and, thus, this maternal language should automatically be revered above all... But now in the English language, a whole lot of extensive and well-researched treatises are coming out concerning the areas such as physics, astronomy, politics, and economy, medicine etc. If you could master both the languages, you can translate those into your own language and that will be of huge help to the Indian people. And the translators will achieve immortality in the memory of the people because of their contribution. Your knowledge will be successful." (Translation: Nirban Nandy) That Head Pundit was none but the dramatist, to 
CODEN: LITIBR

Vol-1, Issue-2 (2 ${ }^{\text {nd }}$ December, 2019)

Page No: 11-18

DOI: 10.47365/litinfinite.1.2.2019.11-18

Section: Article

name Ramanarayan Tarkaratna, whose work Kulinkulasarbaswa will be discussed in this article. As per the details available Ramanarayan Tarkaratna was born at the Harinabhi village in the then district of 24 Parganas to a conservative Brahmin household headed by his father Ramadhan Shiromani. However, after losing both his parents in childhood, Ramanarayan was looked after by his elder brother, Prankrishna Vidyasagar, and his wife. Ramanarayan's education was mostly traditional oriental learning. But the quotation at the beginning strikingly opposes the idea of considering Ramanarayan to be a conservative Brahmin pundit. Otherwise it makes us rethink and revisit Ramanarayan Tarkaratna.

His time was filled with the rhetoric of new advancements. Shibnath Shastri writes in Ramtanu Lahiri O Tatkalin Bangasamaj (Ramtanu Lahiri and His Contemporary Bengal): "The twenty years span between 1825 and 1845 could pretty well be considered as the moment while a new Bengal was taking birth" (Translation: Nirban Nandy). He further points out that this "social revolution" was the result of a collision between the old and the new and in consequence from society to politics to education everything had faced a huge rupture. The advent of colonialism resultantly naturally gave rise to a postcolonial society which brought some qualitative changes in social institutions. India, or Bengal, of $18^{\text {th }}$ century was no exception. It was a time of collision between the old ideals which were slowly perishing and the newness which flourished at a rapid pace. This is the very social revolution which was referred to by Shibnath Shastri, and the automatic result of this social revolution was the birth of a new era dominated primarily by new knowledge and principles. Undoubtedly the void of $18^{\text {th }}$ century was being filled up by next century with its new intellectual principles which were mostly liberal in nature. The majority population of India, that is the Hindu society, was so far bound by the blind ritualistic imitation of Hindu codes of conduct instructed by the Smriti texts. The socio-religious void was first challenged by Raja Rammohan Roy. Raja Rammohan was well-versed in scriptures of many religions and he was also adept in many languages including Bangla, Persian and English. Frustrated with the dogmatic practices of rigid and conservative Hindu society, Raja Rammohan tried his best for introducing liberal western education system in Bengal. Not only education for men, awareness regarding the education for women was also heightening since the very early hours of the $19^{\text {th }}$ century. English educationist Drinkwater Bethune established a school for women in 1849. But almost three decades ago, Rajah Rammohan Roy and his fellow progressive friends alongside the Christian missionaries started campaigning in favour of education for women. On the other hand, the Young Bengal movement led by Henry Louis Vivian Derozio and his students had shaken the apparent stability of the social institution. Rammohan's long engagement against the Sati system reaped its fruit in the year of 1829. In 1856, Ishwarchandra Vidyasagar succeeded in his Widow Remarriage movement alongside the social vice of Kulin system was also challenged. Kulin system and its modus operandi will be discussed in detail while we will indulge into specific discussion about Ramanarayan Tarkaratna and his Kulinkulasarbaswa. The play is all about this Kulin system. Other significant movements of 
CODEN: LITIBR

Vol-1, Issue-2 (2 ${ }^{\text {nd }}$ December, 2019)

Page No: 11-18

DOI: 10.47365/litinfinite.1.2.2019.11-18

Section: Article

the time include the demands of prohibiting child marriage, the abolition of dowry, the annihilation of caste, the annihilation of the prohibition on seafaring by a Hindu so on and forth. All these movements are not really needed to be discussed in scope of this paper. But their mention pertains to the fact that though born and brought up in a conservative Brahmin family, Ramanarayan Tarkaratna must had been acquainted with all these contemporary progress. All these movements primarily centred round the cities. But like urban settlements, rustic life also refused to remain uninformed about the new scenarios. On the other hand, not only the surroundings but adherence to the progressive notions depends also on one's individual progressiveness and liberalism. Our dramatist, Ramanarayan Tarkaratna, was one of those individually progressive and liberal scholars of the time. To be honest he was never ever comparable with his contemporary Ishwarchandra Vidyasagar as the latter was a person of exceptional vigour. But Ramanarayan's mentality was no less modern than that of Ishwarchandra Vidyasagar. For instance, we may again go back to the speech at the beginning of this paper where a Brahmin pundit, whose own academic background was totally traditional, strongly recommends English education and refers to specific branches of study such as physics. Ramanarayan probably even had knowledge, though meagre, of English as we see a group of young men known as 'Nagar' (Citizens) in his play Nabanataka uses English frequently. Unfortunately, we have no consolidated biography of him and most of his life is still unknown and unsearched. Again some scholars have sometimes hinted at his active engagement in the afore-mentioned social movements. For instance, Priyaranjan Sen writes in his essay "Natuke Ramanarayan" (Ramanarayan, the Playwright) published in Prabasi, a Bangla periodical, of Ashwin 1338: "Then some people, who were also like Ishwarchandra Vidyasagar and chose to oppose the various malpractices related to marital institution, stood firmly for widow remarriage and against polygamy respectively. Ramanarayan was one of them." Ramanarayan Tarkaratna's fame primarily lies in his identity as a dramatist. Apparently, we can mistake his contribution only to be delimited within the periphery of his dramatic creations, but otherwise we can say that the success of his dramatic creation lies in his social consciousness. Social consciousness is the elementary tool to delve deep into his creativity and vitality. The title, 'Natuke Ramanarayan' (Ramanarayan, the Playwright), finds its fulfilment only if we admit the vastness it contains: socially conscious, progressive, liberal, litterateur Ramanarayan. To substantiate our point of view, we can cite another quotation from Ramanarayan Tarkaratna's works. In his first major publication, that is the essay Patibratopakhyan (The Tale of the Faithful Wife), he writes: "Now-a-days most of the gentlemen in our land are engaging carefully with the endeavour of educating their sons. The boys, on the other hand, are becoming worthy of praise as they pass a respectable amount of their daily time busying themselves in true fraternity in various knowledge hubs. But the unfortunate women of our country are still being neglected. It is not like that the people of our country have little faith in the capability of women in pursuing education, but otherwise they think, driven by greed, that it is useless to educate women 
CODEN: LITIBR

Vol-1, Issue-2 (2 ${ }^{\text {nd }}$ December, 2019)

Page No: 11-18

DOI: 10.47365/litinfinite.1.2.2019.11-18

Section: Article

because they have no scope to earn." (Translation: Nirban Nandy) Ramanarayan is very much direct in his judgment. I really feel surprised that a Brahmin pundit of almost one-and-a-half centuries ago can think in such a way and be such a brave-heart to claim his thought directly. The judgment he made is not flawless. All people, who stood against education for women, were not greedy. They failed to understand the necessity of the movement. Some of them really had doubt regarding the capability of women in pursuing education. But what Ramanarayan, with this statement, just exposed the power nexus creating the body of knowledge. Knowledge and necessity of knowledge, in Ramanarayan's expression, become a monetary endeavour regulated by the powerful. If even, some people have doubt regarding women's capability that is nothing but a result of patriarchal hegemony which has been working since the early eras of the Hindu civilization the Smritis prohibiting education for women and designating them within the periphery of house as household chores need less intelligence and women are lesser than men in both physical and intellectual prowess. With this regulatory authority behind, knowledge becomes inaccessible or, in other words, the access to knowledge is dependent on one's gender and on the mercy of a self-proclaimed authority. Knowledge acquires a personal as well as political turn. Here I am needed to make a clarification that my point is not that Ramanarayan had theorized the epistemological power-game sitting in Kolkata of 1850s; what I want to say is Ramanarayan had a sharp mind which can hint that knowledge is based on certain power structures. This is where even we lack in our part. We open the pages of Ramanarayan's books with the pre-occupation that a cult figure of Bangla literature, Michael Madhusudan Dutt, rejected his predecessor playwright's creations as bad compositions and, thus, they should be bad. The tendency of worshipping the heroes and to believe in the rhetoric of half-truth shut the doors of multiplicity on our face. It is now high time to get rid of this half-baked truth. We never read Ramanarayan Tarkaratna with our lens but our medium of reading him is Michael Madhusudan Dutt and, thus, reading Ramanarayan becomes an oversimplified task.

Let us now enter the drama, Kulinkulasarbaswa. The play was published in the year 1854. The advertisement of the play informs us that the landlord of Rangpur (now in Bangladesh) Kalichandra Roy commissioned the composition of a play dealing with the vices of the Kulin system pertinent among the Brahmins of that time, and he also mentioned that the play should be titled 'Kulinkulasarbaswa'. He further promised that the compositor of the best composition would be rewarded rupees 50. Ramanarayan sent his composition and he was declared the winner of the competition. A year ago also he was rewarded by the same landlord for his first essay composition that is Patibratopakhyan. After reading Kulinkulasarbaswa, Kalichandra Roy gave Ramanarayan an additional reward of extra 50 
Litinfinite Journal

ISSN: 2582-0400 [Online]

CODEN: LITIBR

Vol-1, Issue-2 (2 ${ }^{\text {nd }}$ December, 2019)

Page No: $11-18$

DOI: 10.47365/litinfinite.1.2.2019.11-18

Section: Article

rupees to print and publish his play as a book. Kulinkulasarbaswa is a six act play. The play moves around and about the vices of Kulin system which maligned the Hindu societal institution of Bengal for a long stretch of time. The Kulin system portrayed the tyrannical voice of the patriarchal social structure which had already rotten by the time of the play being composed. To enter the play, Kulinkulasarbaswa, we need to understand who is a Kulin or what the Kulin system is, as the title of the play suggests the play is all about this system. The emperor of the Sena dynasty ${ }^{1}$ of Bengal, Ballala Sena ${ }^{2}$, devised this Kulin system. Kulin system is known for its rigid marital regulations and rituals as well as for its recognition of polygamy. Men were allowed to marry as many women they wanted to marry, and each marriage bestowed them with a huge amount of dowry. Most of the time, the bride was left at her father's abode where she had to spend her entire life even without meeting her husband once. Little girls were married off to aged persons just to safeguard the reputation of the ancestry because unmarried women were considered to be a real disgrace to her entire clan. However, the system failed to understand the primordial instinct of human being. The left out women were prone to extra-marital affairs and trysts just to satisfy their natural physical need. Most of the time, they bore fruit of the tryst. Interestingly enough, Kulin society, which recognized polygamy and prohibited polyandry, pretended to be unaware of these polyandrous affairs and gave recognition to the 'illegitimate' children because when the 'legal' father visited their wives to see their children, the fathers were paid, and if fortunately, the children were also male, it was confirmed that they would also bring money to the paternal family by marrying multiple girls when they would reach the marital age. The Kulin system was a pretentious act of tightening the social bond but, it gave rise to chaos where the so-called holy bond of marriage became a business. Girls were then the commodity to be sold and to be consumed. While social reformers like Ishwarchandra Vidyasagar chose to fight these social evils face to face, a litterateur like Ramanarayan Tarkaratna chose to take his pen up in his hand to provide the intellectual support to the movement.

Social consciousness is one of the most fundamental elements of Ramanarayan's plays. On the other hand, his drama also reflects the social life of the time. Dramatic creation cannot exist without society. To portray his social consciousness our playwright also welcomes campaigning. Ramanarayan's plays combine a postcolonial consciousness which makes him welcome English education, and employ occasional use of English language in his dialogues; his postcolonial consciousness lies in his approach to the upheaval of newness, and in his ability to overcome his rigid background in favour of a more flexible time to come. I refuse to believe that postcolonial consciousness lies in English elitism and in using western

\footnotetext{
${ }^{1}$ The Sena Empire was a Hindu dynasty which ruled a vast tract of land in eastern India between 1070 CE and 1230 CE.

${ }^{2}$ Ballala Sena was an emperor of the Sena dynasty of Bengal. He was a king of circa $12^{\text {th }}$ century CE. Besides being a strong and revered ruler, Ballal Sena is also known for his conservative endeavours to restructure Bengal Hinduism and to create a rigid code of conduct for the Hindu society
} 
CODEN: LITIBR

Vol-1, Issue-2 (2 ${ }^{\text {nd }}$ December, 2019)

Page No: 11-18

DOI: 10.47365/litinfinite.1.2.2019.11-18

Section: Article

forms of literary practices, but I consider postcolonial thought, in its truest sense, lies in this honest trial by a Brahmin pundit to bridge the gap between the old and the new. It is my opinion that literature re-evaluates this dramatist going beyond form of composition under a new lens. Against the modern standards of dramatic composition, Ramanarayan might not be a composer of great merit. His drama lacks in several literary qualities. His plays are loosely composed. But in his time, until the arrival of Michael Madhusudan Dutt, he was a popular playwright. Otherwise the dramatic idea of his time was altogether different. Bengal Philharmonic Academy honoured Ramanarayan with the 'Hara Coomer Tagore Honour' and wrote: “... in consideration of his Proficiency in dramatic writing and his being the first writer of Bengali Drama in a systematic form." The awarded certificate acknowledged Ramanarayan to be the person who systematized the form of Bangla drama. However, some scholars once considered him to be the first dramatist of Bangla literary canon, though now the credit of composing the first Bangla drama is now conferred upon a Russian, namely Gerasim Steppanovich Lebedev. But we cannot forget that Ramanarayan Tarkaratna was the first playwright who composed original plays based on his time. Thus, the reading of his plays should emphasis more on his social consciousness rather than his dramatic tools. His creations are more a social manifesto rather than being a higher form of abstract art.

Ramanarayan Tarkaratna's artistic as well as intellectual consciousness is combined in his laughter. His creations are mostly farce, socially conscious farce. The laughter he makes is his primary instinct. It almost works like a primordial force that shapes the farcical but real world of drama. Farce usually bears the marks of the time. It appears in a society which has new challenges to face, and which is a time of void and emptiness. These imbalances create laughter. Imbalance is the main source of laughter. The imbalance in the national life produces a whole lot of productive and critical farces and sketches. And thus, Ramanarayan is inclined towards composing farces. He has clearly composed three farces while his other plays also embody farcical undertone. In Kulinkulasarbaswa, all the varieties of laughter are available such as wit, pun, satire, humour. Priyaranjan Sen writes: “... In this, overwhelming elements of laughter are included. It seems that the writer does not only want to portray the chaos of the Kulin society, but he cannot restrain himself from laughing out loud at the imbalances it created." Thus, we see that in a marriage ceremony happening towards the end of the play, the priest chants the mantras and offerings to the god of death, Yama. His soul cries seeing four women being married off to an old man with one of his legs in the grave. Is it really a happy ceremony of marriage or is it a farce in itself where the commodity named women is just being abused?

Kulinkulasarbaswa cannot be marked as a drama per excellence. It is a play of propaganda. The agenda that the play upholds is clearly to portray the rotten Brahmin-led 
CODEN: LITIBR

Vol-1, Issue-2 (2 ${ }^{\text {nd }}$ December, 2019)

Page No: 11-18

DOI: 10.47365/litinfinite.1.2.2019.11-18

Section: Article

society of the playwright's time. The inspiration behind the composition of the play is derived not from a pure intellectual vision but more for raising the propaganda against social evils devised by the Brahmins and the long-stagnant society of the Hindus. Ramanarayan is very much honest about this propagandist nature of his composition. He honestly states: “... the wholesome and close reading of the text is a significant testimonial of how the artificial Kulin system has made the Bengal society rot." (Translation: Nirban Nandy) Most of his characters are type characters. The dramatis personae are often extremely long. It is even impossible to give a summary of the plot because it has no definite beginning, middle, or end. It is loosely woven, rather very loosely. It seems that the writer is more inclined towards the portrayal of multiplicity that he refuses to conceal himself inside a linear storyline. But what we see is that the tiny but multifarious periphery he creates that is very much living, very much real. One example may suffice: Anrita, meaning untruthful, is a matchmaker. As a matchmaker, he is supposed to suggest ideal matches but for Anrita it is a business and for making profit in business, Anrita can even make a match between an aged old man about to die and a young girl. Anrita does not hesitate to say, with ample doses of pun, that he is untruthful, cheater, and cunning. The name of some characters can also be cited which shows Ramanarayan's irony, ready wit, and sharp satire: Anrita (The Untruthful), Adharmaruchi (One who is inclined towards the sacrilege) ${ }^{3}$, Bibahabanik (One who has business of marrying), Udarparayana (One who is gluttonous) $)^{4}$, Abhabyachandra (One who is uncouth), Bibahabatul (One who is unmarried and has a strong desire of marrying) so on and forth. On the other hand, the seeming vulgarity of the womenfolk of the play is quite natural. Their repressed physical desire frees itself as vulgar jokes. They also lack in power and education. They are confined into the so-called security of home. Their desire needs a vent to open out. Thus we see Ramanarayan making an establishment of women where repression collates with laughter, vulgarity, illegitimate trysts, extra-marital affair, sympathy, empathy so on and forth. Dialogue is the heart of a play. But in this particular article I will not be able to engage much with the dialogue as they are in Bangla and no English translation of the play is available. To translate this drama into English keeping the original fervour intact is a mountainous task. Dialogue is a dialectic progression. The journey of dialogue is teleological. But is teleology really possible? Or like the Euclidean postulate, the teleological goal keeps shifting away? This self-contradictory nature of dramatic dialogues reveals the inter- and intra-personal journey of the dramatis personae. In the play, Ramanarayan Tarkaratna employed lively dialogues which gives the play a quick pace, makes the characters realistic, and brightens the situation. 1854, the publication year of Kulinkulasarbaswa, dawns the new era. It will not be hyperbolic if we consider Ramanarayan Tarkaratna to be the paternal figure of mature dialogues which reflect the dialectic postulation of the art. Ramanarayan's project was to bridge the gap between the old and the new. It is quite evident that he has an

\footnotetext{
${ }^{3}$ Interestingly enough, Adharmaruchi is a Brahmin who is expected to be a keeper of the rightfulness.

${ }^{4}$ Gluttony is prohibited for the Brahmins.
} 
CODEN: LITIBR

Vol-1, Issue-2 (2 ${ }^{\text {nd }}$ December, 2019)

Page No: $11-18$

DOI: 10.47365/litinfinite.1.2.2019.11-18

Section: Article

inclination toward Sanskrit dramatic poesy. But he was also open to the new traditions. He is a seeker of the path. His artistic and intellectual psyche is insightful, deep, curious, and honest. Kulinkulasarbaswa has many qualities that make us infer that the pay is a farce. But otherwise, it is not a farce. It is a vast tract of laughter. But the playwright is well aware that the laughter is a masque which shrouds as an undertone the stream of pathos in the drama. The laughter masquerades the pathetic situation women undergo; the pain and uselessness of their daily existence where they have become stagnant and de-human. His play is not a product of a farcical jester but a serious employment of a learned dramatist.

Towards the end of the article, I think there is a necessity to re-emphasise on the point that Ramanarayan Tarkaratna, despite having progressive consciousness, has many technical flaws. The impartial judgment of his plays will never be able to mark them in the highest rank of the Bangla dramatic canon. But, on the other hand, we cannot or we should not forget that it is Ramanarayan Tarkaratna who for the very first time collated the contemporaneous consciousness with the dramatic spontaneity. His realistic and progressive vision had been functional for a long period in guiding Bangla drama the right steps. Undoubtedly, Ramanarayan Tarkaratna guided the Bangla dramatic literature for a long period of time and it will not be an exaggeration to say that he successfully brought life to the icon of Bangla drama with his literary, social, academic, and performance consciousness which was very much postcolonial in nature.

\section{Works cited:}

i. Bandyopadhyay, Asit Kumar. Bangla Sahityer Sampurna Itibritta. $7^{\text {th }}$ edition. Kolkata: Modern Book Agency, 1392 Bengali Calender Year. Print.

ii. Bandyopadhyay, Brajendranath. "Ramanarayan Tarkaratna". Sahitya Sadhak Charitamala. Vol.10(2). Ed. Brajendranath Bandyopadhyay. $4^{\text {th }}$ edition. Kolkata: Bangiya Sahitya Parishat, 1354 Bengali Calender Year.

iii. Bandyopadhyay, Suresh Chandra. Smritishastre Bangali. Kolkata: A. Mukherjee \& Co., 1367. Print.

iv. Bangla Theatre er Gan. Ed. Debjit Bandyopadhyay. New Delhi: Sahitya Akademi, 2003. Print.

v. Bharat. Natyashastra. Trans. Suresh Chandra Bandyopadhyay \& Chhanda Chakraborty. Ed. Suresh Chandra Bandyopadhyay. Kolkata: Nabapatra Prakashan, 1980. Print.

vi. Gupta, Kshetra. Adhunik Bangla Sahityer Itihas. Kolkata: Grantha-Niloy, 1368 Bengali Calendar Year. Print.

vii. Mukhopadhyay, Satyajiban. Drishyakabya Parichoy. Kolkata: Basumati Sahitya Mandir, 1950. Print.

viii. $\quad$ Sen, Sukumar. Bangabhumika. Kolkata: Paschimbanga Bangla Akademi, 1999. Print.

ix. $\quad$ Shastri, Shibnath. Ramtanu Lahiri O Tatkalin Bangasamaj. Ed. Baridbaran Ghosh. $2^{\text {nd }}$ edition. Kolkata: New Age, 2007. Print.

x. Tarkaratna, Ramanarayan. Kulinkulasarbaswa. Ed. Satyabrata Dey \& Sanatan Goswami. Kolkata: Pustak Bipani, 1987. Print. 